Sugerowane cytowanie: Kaliszewska-Henczel M. (2021). Kamishibai w edukacji regionalnej. Strategie tworzenia papierowego teatru przez przyszłych i obecnych nauczycieli, „Edukacja Elementarna w Teorii i Praktyce", vol. 16, nr 1(59), s. 67-78.

\title{
Magdalena Kaliszewska-Henczel
}

\section{Kamishibai w edukacji regionalnej. Strategie tworzenia papierowego teatru przez przyszłych i obecnych nauczycieli}

\section{Kamishibai in Regional Education. Strategies for Creating Paper Theater by Future and Current Teachers}

\section{SŁOWA KLUCZE ABSTRAKT}

kamishibai, Niniejszy tekst traktuje o sposobie wykorzystania papierowego teatru papierowy teatr, w edukacji regionalnej. Wywodzące się z tradycji japońskiej kamishiedukacja regionalna, bai stanowi połączenie sztuki wizualnej i sztuki opowiadania. Histoedukacja literacka ryczną drogę, którą przebyło, by zakorzenić się we współczesnej edukacji (w szczególności w działaniach skierowanych do dzieci w wieku przedszkolnym i wczesnoszkolnym), opisuję w pierwszej części artykułu. Dalsze rozważania poświęcam badaniu, którego celem było poznanie strategii tworzenia papierowych teatrów przez nauczycieli łódzkich szkół i przedszkoli oraz studentów Wydziału Nauk o Wychowaniu Uniwersytetu Łódzkiego, specjalności edukacja wczesnoszkolna i wychowanie przedszkolne, zaangażowanych w projekt „Kamishibai w edukacji regionalnej” (organizowany przez Łódzkie Centrum Doskonalenia Nauczycieli i Kształcenia Praktycznego). Przedmiotem analiz uczyniłam 62 projekty (przygotowane w formie plansz i tekstu lub nagranych filmów) udostępnionych przez badanych na platformie Moodle oraz MS Teams. Zastosowane metody badawcze (analiza dokumentów oraz wywiad swobodny) pozwoliły na podjęcie rozważań na temat doboru tworzywa literackiego oraz potencjału i ograniczeń metody kamishibai. Ostatecznie doprowadziły mnie do opisu strategii projektowania papierowych teatrów, mających popularyzować obcowanie ze sztuką słowa regionu łódzkiego. 


\section{KEYWORDS ABSTRACT}

kamishibai, paper theatre, regional education, literary education
This text presents a way of using paper theatre in regional education. Derived from the Japanese tradition called kamishibai, the theatre is a combination of visual art and storytelling. The historical path it has followed to become rooted in the contemporary education (especially dedicated to preschool and early school children) is described in the first part of the article. Further considerations are related to the research which aimed at learning the strategy for creating paper theatres by teachers of Łódź schools and kindergartens, and by the students of the Faculty of Educational Sciences at the University of Łódź who specialize in early school and preschool education, and who are involved in the project: "Kamishibai in regional education" (organized by the Łódź Centre for Teacher Training and Practical Education). I analysed 62 projects (prepared in the form of charts and texts, or in the form of recorded films) that were made available by the participants on the Moodle and MS Teams platform. The applied research methods (analysis of documents and nondirective interview) allowed me to discuss the choice of literary material and the potential and limitations of the kamishibai method. Eventually, they made it possible for me to describe the strategy for designing paper theaters, which are to popularize contact with the art of the word of the Lodz region.

\section{Wprowadzenie}

Współczesna rzeczywistość (również edukacyjna), nieszczędząca szumu informacyjnego, pęknięć o charakterze aksjologicznym, szybkości i nieprzewidywalności przemian, sprawia, iż niezwykle aktualnie wybrzmiewają słowa Ireny Wojnar:

W czasach, kiedy przeżywamy kolejne narastanie nieprzejrzystości świata, w czasach nowego szaleństwa, brutalności i nihilizmu, przeciw zagrożeniom i dewiacjom proponuję obronę człowieka wrażliwego i poezji jego istnienia. Proponuję kształcenie człowieka, który w sobie samym miałby znajdować źródła bogactwa i siły, a pomocą w tym poszukiwaniu byłoby przeżywanie sztuki, zwierciadła ludzkich możliwości (Wojnar 1994: 91).

Świat szkoły i przedszkola domaga się obecności w życiu dziecka osób będących w stanie pobudzić myślenie i odczuwanie za pośrednictwem literatury, teatru, obrazów. Pożąda zatem „artystów, posiadających uzupełniające się: umiejętności i wrażliwość pedagoga, angażującego ludzi w zdobywanie doświadczeń w sztuce, poprzez nią lub na jej temat” (Booth 2003: 11). Nauczyciel artysta, czy też - nauczyciel „sztukmistrz” (Zalewska-Pawlak 2013: 8) w kontekście wczesnej edukacji może stać się wsparciem dla uczniów, zanurzonych w rzeczywistości okrytej „utkaną przez ludzi siecią 
symboliczną" (Wojnar 1994: 82), umożliwić nie tylko procesy związane z kompensacyjnym oddziaływaniem słowa, obrazu, teatru, zakorzenieniem się poprzez obcowanie ze sztuką w „małej ojczyźnie”, ale również we wrażliwym i twórczym nieustannym stwarzaniu samego siebie. Idea wychowania przez sztukę dotyka bowiem przestrzeni całożyciowej: „aby żyć w zgodzie ze sobą i światem, należy posiąść umiejętność kreacji” (Ungeheuer-Gołąb 2011: 160).

Potencjał prorozwojowy, budowany na fundamencie spotkania z dziełami artystycznymi (oraz podjęciem procesu twórczego), zakorzeniania w myśleniu pedagogów kategorii teatru i literatury (Szewczyk-Kowalewska 2017), skłania również do rozważań dotyczących przenikania się doświadczeń dzieci i nauczycieli, dla których tworzenie sztuki (zwłaszcza tej o charakterze synkretycznym - a taką właśnie jest sztuka kamishibai) nieść może potencjał terapeutyczny. Tak ważny w aktualnej sytuacji permanentnego zagrożenia i niepewności.

\section{Papierowy teatr - od gaito do kyouiku kamishibai}

Źródła papierowego teatru wpisane są w długą tradycję oralną literatury ludowej w Azji. Uważa się, że praktyka ta powstała w Chinach, migrując później na terytorium japońskie. Właśnie w Japonii recytację opowieści wraz z towarzyszącymi im obrazkami wykorzystywali w świątyniach buddyjscy mnisi, nauczający o bogach i historiach świątyń. Składający się z poziomego papieru zwój obrazkowy, rozwijany na „ekranie” (hirofumi) uważany jest za „poprzednika” kamishibai, a jego historia sięga już XI i XII wieku (Marqués Ibáńez 2017). Papierowy teatr w swojej obecnej formie spopularyzowany został jako rodzaj opowieści ulicznych w latach dwudziestych XX wieku (szczyt popularności osiągając w latach 50.), stając się środkiem uzyskiwania dochodów w czasach załamania gospodarczego (Vukov 1997). Szacuje się, że w latach Wielkiego Kryzysu trzy tysiące gawędziarzy działało w mieście Tokio, w całej Japonii zaś liczba ta oscylowała w granicach trzydziestu tysięcy. Wędrowni artyści, podróżujący na rowerach między wioskami, zachęcali mieszkańców do kupna słodyczy, zabawiając ich opowieściami. Swoje przybycie ogłaszali stukając dwoma kawałkami drewna (hyoshigi). Dzieci, które kupiły cukierki, zajmowały miejsca tuż przy tylnej części roweru, do którego opowiadacz przymocowywał skrzynkę (butai), pozostali mogli zająć dalsze miejsca i nadal uczestniczyć w „papierowym przedstawieniu”.

Gawędziarze kamishibai, manipulując kartami wewnątrz małej drewnianej skrzyn$\mathrm{ki}$, naśladowali popularny styl działania werbalnego, stosowany przy wczesnych projekcjach filmowych. Upowszechniająca się telewizja i film w istocie nawiązywały swą formą do ulicznego papierowego teatru (gaito kamishibai), by (na przełomie lat 50 . i 60. ubiegłego wieku) przesądzić o jego odwrocie. W Japonii wczesne filmy rzadko 
były faktycznie nieme - narratorzy filmowi regularnie zabawiali widzów wykonywaną ustnie ścieżką dźwiękową. Charakterystyczną cechą ulicznych opowieści było również stosowanie cliffhangerów (Say 2005: 5) - momentów napięcia, dzięki którym artyści mieli pewność, że widownia będzie skłonna do powrotu na przedstawienie kolejnego dnia. Istotny wydaje się w tym kontekście również fakt prezentowania historii o charakterze epizodycznym (McGowan 2015). Uliczni opowiadacze w celu uatrakcyjnienia widowiska „obudowywali” także swoje spektakle atrakcjami: quizami i kalamburami (także i do nich wykonywali ilustracje), w których widownia miała szansę wygrać drobne nagrody. Rosnąca popularność kamishibai, wymagająca od twórców pracy przede wszystkim nad wizualną stroną przedstawienia - projektowaniem kart, powodowała nieprzykładanie większej wagi do tworzenia tekstów na rewersach ilustracji. W istocie zatem improwizacja stanowiła charakterystyczną cechę sztuki ulicznej, jej wykonawcy przekazywali między sobą, jedynie skrótowo, informacje o zarysie fabuły - zestawy kart nierzadko wszak „wędrowały” między kilkoma gawędziarzami, skupionymi wokół swego rodzaju wypożyczalni materiałów wizualnych.

Skrypt fabularny na odwrotach ilustracji (współcześnie powszechnie stosowany w Polsce m.in. w materiałach opracowywanych przez wydawnictwo Tibum, Risprint, Kokoszka, Kreatibaj, Art Wood), choć pojawiał się również w odniesieniu do ulicznego kamishibai - gdy pod koniec lat 30. władze wymogły na artystach ulicznych spisywanie tekstu opowieści w celu ich monitorowania (McGowan 2015) - łączy się przede wszystkim z pedagogiczną odsłoną papierowego teatru (kyouiku kamishibai), którego inicjatorką była chrześcijańska misjonarka Imai Yone (Bingushi, Taneichi 2005). Kiedy na początku lat 30. próbowała otworzyć szkółkę niedzielną w Tokio, wielu z jej niedoszłych podopiecznych wybiegało na ulicę, gdy tylko usłyszeli stuknięcie hyoshigi, ogłaszające przybycie gawędziarza. Imai uznała, że kamishibai jest potężnym medium komunikacji i perswazji, które może zostać wykorzystane również w celach szerzenia chrześcijaństwa. Od 1932 roku zaczęła zatrudniać artystów projektujących ilustracje do historii biblijnych, do których opracowywała autorskie skrypty. W swych działaniach naśladowała system wypożyczalni ulicznych performerów, w którym te same historie mogły być rozpowszechniane przez wielu gawędziarzy, dzięki czemu docierały do coraz szerszej publiczności. Imai nawiązywała w swej pracy do realiów ówczesnej sztuki ulicznej (McGowan 2015; 2019), skierowała jednak kamishibai w stronę oficjalnych działań pedagogicznych. Jej zinstytucjonalizowane działania zaowocowały z czasem założeniem Wydawnictwa Kamishibai Kankō Kai. Można uznać ją zatem za inicjatorkę postrzegania papierowego teatru w relacji do procesu uczenia się, rozwoju emocjonalnego i poznawczego dziecka.

Obecnie kamishibai praktykowane jest przez pedagogów na całym świecie - stowarzyszenie IKAJA, prowadzące działania popularyzatorskie i edukacyjne w tym zakresie, zrzesza obecnie ponad trzystu członków z pięćdziesięciu czterech krajów 
(m.in. z Afganistanu, Brazylii, Kanady, Nigerii, Słowenii). Celebrując Światowy Dzień Kamishibai (7 grudnia), zaproponowano ponad sto czterdzieści wydarzeń w dwudziestu dwóch krajach świata - także w Polsce. Metoda zajmuje przynależne jej miejsce także w refleksji badaczy i praktyków - namysł nad sztuką papierowego teatru, jej potencjałem edukacyjnym, terapeutycznym, komunikacyjnym i międzykulturowym prezentowali prelegenci międzynarodowego sympozjum The Art of Kamishibai: The Word of the Image and the Image of the Word, zorganizowanego w 2018 roku przez Słoweński Instytut Teatralny.

\section{W stronę tezukuri kamishibai - nauczyciele i studenci jako twórcy papierowych teatrów w kontekście edukacji regionalnej}

Celem przeprowadzonych badań uczyniłam poznanie strategii tworzenia tezukuri kamishibai - samodzielnie stworzonych papierowych teatrów (McGowan 2010: 10), zaprojektowanych w oparciu o literaturę postrzeganą jako element edukacji regionalnej. Twórcami teatrów byli nauczyciele łódzkich szkół i przedszkoli (5) oraz studenci Wydziału Nauk o Wychowaniu Uniwersytetu Łódzkiego, specjalności edukacja wczesnoszkolna i wychowanie przedszkolne (57), zaangażowani w projekt „Kamishibai w edukacji regionalnej” organizowany przez Łódzkie Centrum Doskonalenia Nauczycieli i Kształcenia Praktycznego. Przedmiotem analizy uczyniłam 62 projekty (przygotowane w między marcem a listopadem 2020 roku w formie plansz i tekstu lub nagranych filmów), udostępnione na platformie Moodle oraz MS Teams. Po ukończeniu tezukuri przeprowadziłam również swobodne nieskategoryzowane wywiady grupowe (z uwagi na wytyczne epidemiologiczne spotkania z respondentami odbyły się za pośrednictwem aplikacji MS Teams), które otworzyły przestrzeń dla swobodnego opisywania doświadczeń, tworzenia własnych definicji sytuacji oraz ujawniania istotnych opinii i postaw (Juszczyk 2013: 145). Usytuowanie w roli uczestnika projektu (mającego wymiar artystyczny), nauczyciela oraz badacza implikowało nawiązanie do metodologicznej a/r/tografii - artist, researcher teacher (Springgay, Irwin, Wilson Kind 2005).

Projekt „Kamishibai w edukacji regionalnej” zainicjowany w listopadzie 2019 roku przez Katarzynę Gostyńską, doradcę z Ośrodka Edukacji Europejskiej i Regionalnej Łódzkiego Centrum Doskonalenia Nauczycieli i Kształcenia Praktycznego, miał na celu promowanie metody papierowego teatru wśród nauczycieli oraz integrację i zawiązanie współpracy osób, wykorzystujących w pracy z dziećmi elementy edukacji regionalnej, odnoszącej się do kontekstu najbliższej okolicy i społeczności lokalnej. Działania z zakresu edukacji regionalnej dotyczą głównie wyposażenia młodego 
człowieka w informacje odnoszące się do historii rodzimego regionu (Grabowski 2010: 11), ich praktykowanie wykracza jednak poza poziom rozwoju poznawczego, stanowi bowiem fundament dla aktywnego i świadomego działania, „wzmacniając siły jednostki poprzez poznanie i zrozumienie siebie oraz swojej najbliższej kultury, w efekcie pozwala dostrzegać odmienności oraz poszukiwać sposobów wzajemnego zrozumienia, porozumienia i współpracy" (Nikitorowicz 2009: 219).

Część projektu, w którą zaangażowani zostali studenci II roku pedagogiki, specjalności edukacja wczesnoszkolna i wychowanie przedszkolne Uniwersytetu Łódzkiego, rozpoczęła się w marcu 2020 roku i - z uwagi na ogłoszenie zagrożenia epidemicznego - przeprowadzona została w formie zdalnej poprzez spotkania za pośrednictwem aplikacji Microsoft Teams oraz platformy e-learningowej Moodle. Kandydaci na nauczycieli, pracując nad własnymi kompetencjami okołoteatralnymi w kontekście edukacji małego dziecka (realizujący równolegle projekty teatru lalkowego i teatru żywego aktora w ramach przedmiotu „edukacja teatralna z metodyką"), po wprowadzeniu w założenia metody, tworzyli tezukuri kamishibai związane z regionem, z którego pochodzą, lub w którym mieszkają (nie zawsze był to region łódzki).

Ostateczną wersję prezentacji stanowiły prace składające się z przygotowanych $\mathrm{w}$ formie zeskanowanej kart i tekstu, bądź upublicznione w tworzywie filmowym, w którym wykadrowane zostały przekładane wraz z biegiem fabuły ilustracje. Uczestnicy, którzy decydowali się na własnoręczne wykonanie butai, zwracali uwagę na całościowe, ich zdaniem, postrzeganie skrzynki-sceny oraz ilustracji: „Chyba dopiero razem sprawiają wrażenie, że robimy coś wyjątkowego, jesteśmy w teatrze”. Zbliżenie kamishibai do „tradycyjnej” formy przedstawień przywołały również nauczycielki, uprzednio wykorzystujące zajęcia z papierowym teatrzykiem.

Projekty, w których ujawniła się nieobecność butai, także przynależą do formy papierowego teatru (Ishiguro 2017: 92; Karpenko 2018: 87), jednak zabiegi skutkujące „ukryciem” opowiadającego (czy to za pośrednictwem kadrowania, czy w sytuacji zasłonięcia go rodzajem kurtyny - jak w przypadku prezentacji wiersza Zoo w Łodzi Eugeniusza Dolata) redukują możliwość ekspresji, opierającej się wówczas na prezentowanych obrazach i głosie wykonawcy (nie ujawniając jego mimiki). Kadrowanie filmów z pominięciem osoby opowiadającej stanowiło egzemplifikację różnych poziomów ważności nadanych poszczególnym elementom kamishibai („Chciałam jak najwyraźniej pokazać ilustracje, one przede wszystkim mają przykuwać uwagę”; „Gdyby kadrowanie było inne - nie byłoby dobrze widać kart”).

Motywacji owego ukrycia doszukiwać można się także w indywidualnych cechach twórców, mających przełożenie na partycypowanie w przestrzeni wirtualnej („Nie do końca chciałabym, żeby ten film pozostał w Internecie, źle bym się z tym czuła”; „Wstydzę się pokazywac””; „Nie chcę być poddawana krytyce”; „Nie chcę, żeby ktoś w nieodpowiedni sposób wykorzystał mój wizerunek"). Wstyd lub strach przed 
narażeniem na śmieszność wiązać może się z niskim poziomem zaufania społecznego i brakiem pewności co do własnych kompetencji, na co zwracali uwagę również nauczyciele zaangażowani w projekt, przywołując własne doświadczenia ze studentami odbywającymi praktyki, czy nauczycielami rozpoczynającymi pracę w szkołach i przedszkolach.

Interesujący okazał się mechanizm „wiązania” tekstu z miejscem, ujawniający się poprzez różne strategie wyboru (bądź tworzenia) tekstów - fundamentów papierowych teatrów. Sięgano do literatury traktującej o Łodzi bądź o regionie łódzkim, lub (rzadziej) o innych miejscach, regionach, bliskich uczestnikom projektu. Przykładem miejsc „pozałódzkich” był teatrzyk o Tarnowie na podstawie tekstu Aleksandry Janus Kilka trudnych chwil z życia Filipa Smutkotapka i legenda O Grecie z Czermina $i$ Wojtusiu organiście, związana z Przysuchą. Drugą strategią okazał się wybór utworu pisarza związanego z miastem. Ostatnią - stworzenie tekstu autorskiego.

W powyższych drogach postępowania ujawnia się znaczenie lokalnego dziedzictwa kulturowego jako niezbędnego elementu tożsamości zarówno jednostkowej, jak i społecznej, sprzyjającej zakorzenieniu w „małej ojczyźnie” (Nikitorowicz 2009: 214). W istocie fundamenty kamishibai zawierały w sobie pożądane cechy utworów, wpisanych w kontekst realizowania edukacji regionalnej, które wymienia Krystyna Zabawa, charakteryzując podania, legendy i baśnie przez pryzmat potencjału wywoływania oddźwięku emocjonalnego, zainteresowania i pobudzania do działania dzieci w wieku przedszkolnym i wczesnoszkolnym (Zabawa 2010: 53-57).

Wybierano utwory stosunkowo krótkie (poezję prezentowano zawsze w oryginalnym brzmieniu, prozę jednak poddawano edycji w celu dostosowania długości do możliwości aktywnego odbioru, co autorzy motywowali chęcią uniknięcia znużenia młodszych dzieci). Istotną kwestią stało się także uwspółcześnienie języka opowieści, rezygnacja z dużego nagromadzenia archaizmów leksykalnych i składniowych. Autorzy, którzy decydowali się na umieszczenie tekstu w niezmienionym brzmieniu, zwracali jednak uwagę na elastyczność i możliwość bieżącego dostosowywania historii do wieku danej grupy odbiorców, co wskazuje na wciąż aktualną rolę improwizacji gawędziarza kamishibai.

Wśród uzasadnienia wyboru danego tekstu odnoszono się do jego potencjału pod względem przyszłej interpretacji głosowej: „W Lokomotywie i w Rzepce pojawiają się wykrzyknienia, onomatopeje, które ożywiają tekst”; „Operowanie tempem, intonacją, głośnością sprawia, że opowiadanie staje się ciekawsze, zwłaszcza, gdy nie widać naszych twarzy, a ekspresja musi się oprzeć na ilustracji i na naszym sposobie mówienia”.

Za utwory „z potencjałem” uznano także teksty, w których występował dialog - ze względu na możliwość nadania specyficznego charakteru (często humorystycznego) postaciom za pomocą głosu. 
Uczestnicy projektu eksponowali w pracach znane dzieciom szczegóły topograficzne. To one, zawarte w fabule, mogły stać za wyborem tekstu-fundamentu - jak w przypadku nauczycielki ze szkoły znajdującej się na osiedlu Retkinia (jedno z miejskich blokowisk, dawniej podłódzka wieś). Szczególnie cenne wydaje się właśnie poszukiwanie (tworzenie) narracji o miejscach, którym, wydawałoby się, nie przynależy żadna legenda, bajka. „Posiadanie” narracji byłoby w takim przypadku elementem zachodzącego wśród mieszkańców osiedla procesu więziotwórczego. Wybór miejsc „bliskich sercom” autorów (choćby na podstawie wspomnień z własnego dzieciństwa) otwiera możliwość postrzegania ich jako przestrzeni potencjału, miasto zaś jawi się jako „wieloraka chora, wiecznie otwarta na kolejne znaczenia i nimi nienasycona; miejsce, które nieskończenie - w projektującej przyszłość rekonstrukcji przeszłości w teraźniejszości - tworzy nowe podmiotowości” (Mendel, Theiss 2016: 65). Taka optyka postrzegania może zaś inicjować procesy społeczne o charakterze inkluzyjnym, angażujące człowieka do współtworzenia kultury (por. Gulczyńska, Wiśniewska-Kin 2020). Charakterystyczne elementy przestrzeni pojawiały się także w tekstach autorskich - np. jako nawiązania do rzeźb Łodzi Bajkowej - inicjatywy w ramach której stworzono rodzinny szlak turystyczny śladami pomników postaci z seriali dla dzieci i filmów Studia Małych Form Filmowych Se-ma-for.

Wśród legend, które stanowiły kanwę papierowych teatrów, uczestnicy projektu wybrali:

- Legendę o uniejowskiej Biatej Damie, w której piękna uniejowianka obroniła przed zbójcami mieszkańców zamku oraz ukryty w nim skarb;

Legendę o Łowiczu - na pamiątkę pelikanów, które pomogły zagubionemu na łowickich ziemiach księciu - właśnie te ptaki umieszczono na herbie Łowicza;

- Legendę o Mikotaju Koperniku, który zgubit swoje pióro - o Kiernozi w powiecie łowickim;

- Legendę o Pannie Piotrkowskiej, której portret wykorzystano w szkicowanym planie nowej osady fabrycznej;

- Księżniczkę z pótnocy, czyli historię pierwszych osadników Retkini - o pochodzeniu przedmiotów (obecnie znajdujących się w Muzeum Archeologicznym i Etnograficznym w Łodzi) z grobu odkrytego na Retkini w 1935 roku, krótko przed przyłączeniem do Łodzi;

- Legendę o Januszu (czy też: Legendę o Januszu i Sarze), w której na miejscu początkowego schronienia (dno łodzi) bohaterowie zakładają przyszłe miasto Łódź;

- Piekielne maszyny, czyli jak u Scheiblera bies para dmuchat - o Węsadzie (kuzynie diabła Boruty), który uparł się, by przyjęto go do pracy u samego łódzkiego króla bawełny, pana na Księżym Młynie.

Wśród wierszy wiodącym wyborem była twórczość Juliana Tuwima. Przygotowano kamishibai na podstawie utworów: Rzepka, Lokomotywa, Cuda i dziwy, Ptasie radio, 
Zosia Samosia, Abecadto, Bambo, Spóźniony stowik, Dżońcio, Kotek, Pan Maluśkiewicz i wieloryb, Stót, Stoń Trąbalski. Inspirację stanowiła również poezja Wandy Chotomskiej (Przygody jeża spod miasta Zgierza), Malwiny Sędzikowskiej (O tym jak Franek do Zgierza jechat), Małgorzaty Kaczmarek (Ballada o Julku), Elżbiety Boryniec (Lokomotywa pana Juliana), Mirosławy Lis (Królofelki-Kartofelki), Eugeniusza Dolata (Zoo $w$ Łodzi), Roberta Huzika (Maty wędrowiec). Jedna ze studentek wybrała również fragmentami pisaną wierszem książeczkę Przedszkolak chodzi po mieście Łodzi Ewy Ćwikły, w której skrzat Łodziaczek oprowadza dzieci po najbardziej charakterystycznych zakątkach miasta.

Podążając tropami baśni, legend i poezji, zdecydowano się również na stworzenie własnych tekstów. Tak powstały prozatorskie utwory „łódzkie”: Królowa snów (oniryczna opowieść, w której zagubionemu w Łodzi Obłoczkowi - Snowi, pomóc usiłuje Julian Tuwim, pan Wieczór, koty: Filemon i Bonifacy oraz pingwin Pik-Pok), Spacer po ulicy Piotrkowskiej (w której w czasie pełni księżyca na reprezentacyjnej ulicy miasta ożywają wszystkie posąi), Papużka Anużka (o tym jak to pewna papuga została łódzką performerką), O Jednorożusiu, czyli łódzkim jednorożcu (w nawiązaniu do rzeźby autorstwa Tomohiro Inaby, która poznaje w Łodzi Plastusia, Misia Uszatka oraz Filemona i Bonifacego), Calineczka i jej droga do domu (o Andersenowskiej bohaterce przemierzającej łódzkie ulice, Pasaż Róży, by ostatecznie odnaleźć szczęście w Łódzkim Ogrodzie Botanicznym), Farbiarz pana Geyera (inspirowany sylwetką Ulankiewicza - farbiarza, o którym mówiono, iż natchnienia do pracy poszukiwał, wyłapując motyle na podłódzkich łąkach) oraz wiersz Łódź. Kanwą kamishibai stała się także biografia Juliana Tuwima - Historia Juliana Tuwima.

Podejmując refleksję nad planowaną pracą oraz odnosząc się do dotychczasowych doświadczeń, uczestnicy projektu stawiają papierowy teatr jako punkt wyjścia do różnorodnych aktywności dzieci. Propozycje: samodzielnego tworzenia własnych kart (bądź realizacja tego zadania w grupach) na podstawie opowieści, pobudzania aktywności słownej poprzez użycie ilustracji o symbolicznym, minimalistycznym charakterze, zastosowania papierowego teatru jako punktu wyjścia do tworzenia spektaklu żywego aktora - dowodzą, że kamishibai inicjować może działania o charakterze intersemiotycznym.

\section{Konkluzje}

Strategie tworzenia papierowych teatrów, których inspiracją stawały się wydarzenia historyczne, legendy związane z regionem, biografie, miejsca - ujawniły ścieżki, którymi podążyli twórcy, eksplorując tematykę historyczną, topograficzną, językową, literacką Łodzi i regionu. Zarówno bycie twórcą, jak i odbiorcą powstałych w ramach 
projektu prac - inicjuje optykę postrzegania relacji między miastem/regionem (ze wszystkimi ich promieniującymi znaczeniami) a jego mieszkańcami, opartej na Brunerowskim skutecznym zdziwieniu. Wartość studenckich i nauczycielskich kamishibai tkwi zatem nie tylko w ich potencjale popularyzatorskim - promowaniu metody papierowego teatru, regionu lub twórczości autorów tekstów-fundamentów. Same w sobie stanowić bowiem mogą efekt wrażliwego patrzenia na otaczającą rzeczywistość, ujawniającą się w doborze utworów, poddawaniu ich redakcji, czy tworzeniu własnych scenariuszy z myślą o dziecięcym odbiorcy.

Szczególnie cenny w tezukuri kamishibai wydaje się fakt otwarcia dialogu poprzez „podarowanie” uczniom osobistego dzieła, którego wyjątkowość emanuje oczywiście na płaszczyźnie fizycznego wytworu, choć jest to tylko powierzchnia (w dobie powszechnego obudowania skomercjalizowanymi pomocami dydaktycznymi - także wyjątkowa), pod nią jednak kryje się podarunek głębszy i cenniejszy - doświadczenie własnego oswojenia pewnego wycinka świata. To, w jaki sposób dobrany został tekst-fundament, co (i dlaczego) przedstawiono na ilustracjach.

Teksty i obrazy „zamknięte” w papierowym teatrze są źródłem opowieści o Łodzi i jej okolicach, ale i na owe przestrzenie spoglądać możemy od tej pory inaczej na kamienice i pomniki, podwórka, parki i ulice, o których dotąd nikt jeszcze nie opowiedział historii, nie ułożył baśni, wiersza. One zaś tylko czekają, by w końcu

je wypowiedzieć. Źródłem zdziwienia stają się nie tylko elementy dalekie, nieznane, ale również te, które były przedmiotem uprzedniej percepcji - mogącej w trakcie obcowania z kamishibai zaowocować nowymi skojarzeniami, powiązaniami, nadaniem nowych znaczeń.

Pamiętając o tym, że twórczego ucznia może przygotować tylko twórczy nauczyciel, ten, który: „promuje w pracy nowatorskie pomysły, jest otwarty na pomysły innych, stale wzbogacający swą wiedzę merytoryczną i podnoszący swoje kompetencje zawodowe" (Szkolak 2011: 90), niezwykle istotne okazało się podjęcie owego wysiłku twórczego, zwłaszcza mającego miejsce mimo piętrzących się przeszkód. Nauczyciele chcący, mimo owych niedogodności, efektywnie działać, powinni mieć w sobie gotowość do współpracy ze środowiskiem, dzielenia się doświadczeniami, podjęcia poszukiwań (metod, form, zasobów), a także odwagę do eksperymentowania (Rautiainen 2020) poprzez odnajdywanie nowych dróg do realizacji celów edukacyjnych.

\section{Bibliografia}

Bingushi K., Taneichi J. (2005). Kamishibai as Media in Early Childhood Care and Education - a Consideration Based on the History of Kamishibai. „St. Mary's College: Annual Report of Studies", Vol. 27, s. 53-67. 
Booth E. (2003). Seeking Definition: What is a Teaching Artist? „Teaching Artist Journal”, Vol. 1 Issue 1, p. 5-12. DOI: 10.1080/15411796.2003.9684265.

Grabowski M. (2010). Edukacja regionalna w kontekście teoretycznym. „Edukacja Elementarna w Teorii i Praktyce” nr 15-16/1-2, s. 5-13.

Gulczyńska A., Wiśniewska-Kin M. (2020). Od „wjeżdżania w bramy” do „otwierania (sie) bramy”. Przyktad animacji kultury upetnomocniajacych gtos dziecka w procesie rewitalizacji miejskiej. „Problemy Wczesnej Edukacji, nr 50(3), s. 55-65. DOI: 10.26881/ pwe.2020.50.05

Ishiguro H. (2017). Revisiting Japanese Multimodal Drama Performance as Child-Centred Performance Ethnography: Picture-Mediated Reflection on 'Kamishibai', In. Chemi, T. $\& \mathrm{Du}, \mathrm{X}$. (Eds.), Arts-Based Methods in Education around the World, Denmark: River Publisher. s. 89-105.

Juszczyk S. (2013). Badania jakościowe w naukach spotecznych. Szkice metodologiczne. Katowice: Wydawnictwo Uniwersytetu Śląskiego.

Karpenko Y. (2018). The Art of Kamishibai as an Educational Cognitive Technology in FLT in Primary School in Ukraine, [w:] Čepeljnik M. (Ed.) The Art Of Kamishibai. Proceedings, International Symposium The Art of Kamishibai: The Word of the Image and the Image of the Word, Ljubljana: Slovenski gledališki inštitut (zanj Mojca Jan Zoran), s. 86-97.

Marqués Ibáñez A. (2017). Kamishibai: An intangible cultural heritage of Japanese culture and its application in Infant Education. „Képzés és Gyakorlat” („Training and Practice”), Volume 15, Issue 1-2, s. 25-44. DOI: 10.17165/TP.2017.1-2.2

McGowan T. (2010). The Kamishibai Classroom: Engaging Multiple Literacies Through the Art of "Paper Theater". Santa Barbara :ABC-CLIO.

Mendel M., Theiss W. (2016). Pamięć i miejsce in potentia: o mieście petnym. „Pedagogika Społeczna” nr 1(59), s. 53-66.

Nikitorowicz J. (2009). Edukacja regionalna i międzykulturowa. Warszawa: Wydawnictwa Akademickie i Profesjonalne.

Rautiainen A. (2020). Finland: Innovation and Creativity in the Time of Covid-19, referat wygłoszony 12.08.2020 na konferencji „The Anywhere School 2020”.

Say A. (2005). Kamishibai Man. Boston: Hooghton Mifflin Company, Walter Lorraine Books.

Shimokawa K. (ed.). (2002). Kindaikodomoshinenpyo (Modern History of Children): 1868-1926. Vol. 1 Meiji and Taisho era. Tokyo: Kawade Shobo Shinsha. The department of social affairs of Tokyo City, Kamishibainikansuruchousa (A survey of Kamishibai in Tokyo).

Springgay S., Irwin R.L., Wilson Kind S. (2005). A/r/tography as Living Inquiry Through Art and Text. „Qualitative Inquiry” nr 11 (6).

Szewczyk-Kowalewska I. (2017). Magia literatury i teatru - zapomniane pojęcia $w$ terapii i wspieraniu dziecka zdrowego i dotkniętego choroba. "Zeszyty Naukowe Wyższej Szkoły Humanitas. Pedagogika”nr 15, s. 113-124. 
Szkolak A. (2011). Kompetencje pedagogiczne nauczycieli wczesnej edukacji — relacja z badań wtasnych, [w:] Nauczyciel wczesnej edukacji w badaniach i praktyce edukacyjnej, J. Bonar (red.), Łódź: Wydawnictwo Uniwersytetu Łódzkiego, s. 90-103.

Ungeheuer-Gołąb A. (2011). Wychowanie przez sztukę w edukacji literackiej dziecka. „Chowanna" nr 1, s. 151-161.

Vukov E. (1997). Kamishibai, Japanese Storytelling The Return of An Imaginative Art, „Education About Asia”, Volume 02:1 (Spring 1997): Teaching About the Religions of Asia.

Wojnar I. (1994). Trzy wymiary estetycznej samowiedzy cztowieka. „Sztuka i Filozofia” nr 8, s. $77-92$.

Zabawa K. (2010). Literatura dla dzieci w edukacji regionalnej. „Edukacja Elementarna w Teorii i Praktyce" nr 15-16/1-2, s. 52-60.

Zalewska-Pawlak M. (2013). Sztukmistrze XXI wieku. Rzecz o pedagogach wychowujacych przez sztukę. Eódź: Wydawnictwo Uniwersytetu Eódzkiego.

\section{Netografia}

McGowan T. (2015). The Many Faces of Kamishibai (Japanese Paper Theater): Past, Present, and Future. https://aboutjapan.japansociety.org/content.cfm/the-many-faces-ofkamishibai [dostęp: 10.10.2020].

McGowan T. (2019). Gospel and War Propaganda Take to the Streets! The Rise of "Educational Kamishibai", https://blogs.princeton.edu/cotsen/tag/imai-yone/ [dostęp: 13.11.2020].

\section{ADRES DO KORESPONDENCJI}

Magdalena Kaliszewska-Henczel

Uniwersytet Łódzki, Wydział Nauk o Wychowaniu

Katedra Pedagogiki Wieku Dziecięcego

e-mail: magdalena.henczel@uni.lodz.pl 